\title{
A Comparative Analysis for the Enhancement of Design of Local Cultural Mobile Applications
}

\author{
Analisis Perbandingan untuk Peneguhan Rekaan Aplikasi Mudah Alih Budaya \\ Tempatan
}

\author{
Shamsul Arrieya Ariffin ${ }^{1}$ \\ ${ }^{I}$ Faculty of Arts, Computing, and Creative Industry, Universiti Pendidikan Sultan Idris; shamsul@fskik.upsi.edu.my
}

\begin{abstract}
Culturally appropriate design guidelines could support developers in designing good mobile applications for users. Many studies in developing countries have been conducted without considering the local cultural aspects of the mobile applications for the user interface design. Therefore, this study aims to investigate the usability of mobile applications for three local cultural applications in Malaysian universities to improve the design of mobile applications. The research approach of this article emphasizes the descriptive quantitative results from heuristic evaluation between academics and students in the use of three mobile apps. According to the findings, the academics' preferences are Jawi, Songket, and Batik, in ascending order, while the students' preferences are Songket, Jawi and Batik in ascending order. Consequently, both groups preferred Batik as it attains higher means in the heuristic evaluation. Due to the high ranking of means for all the design principles, this study provides new insights into the prospect of four cultural guidelines for local cultural mobile applications in addition to the general usability design guidelines.
\end{abstract}

Keywords: Local cultural design principles, mobile applications, usability, mlearning.

\section{Abstrak}

Garis panduan rekaan yang sesuai dengan budaya boleh menyokong pembangun dalam mereka bentuk aplikasi mudah alih yang baik untuk pengguna. Banyak kajian di negara membangun telah dijalankan tanpa mempertimbangkan aspek budaya tempatan bagi rekaan antara muka pengguna aplikasi mudah alih. Oleh itu, kajian ini bertujuan untuk mengkaji kebolehgunaan aplikasi mudah alih untuk tiga aplikasi budaya tempatan di universiti di Malaysia. Pendekatan kajian dalam artikel ini menekankan hasil kualitatif deskriptif dari penilaian heuristik antara akademia dan pelajar dalam penggunaan tiga aplikasi mudah alih. Menurut hasil dapatan, keutamaan academia adalah Jawi, Songket dan Batik, dalam turutan menaik. Akibatnya, kedua-dua kumpulan memilih Batik kerana ianya mempunyai makna yang tinggi dalam penilaian heuristik. Hasil dari kedudukan min yang tinggi bagi semua prinsip rekaan, kajian ini memberikan pandangan baharu terhadap prospek untuk empat garis panduan untuk aplikasi mudah alih budaya tempatan selain dari garis panduan reka bentuk kebolehgunaan umum.

Kata kunci: Prinsip rekaan budaya tempatan, aplikasi mudah alih, kebolehgunaan, m-pembelajaran. 


\section{INTRODUCTION}

Usability may include culturally appropriate design guidelines or principles of the user interface of applications used in mLearning or mobile learning. There is lack of guidelines for incorporating local culture in the design of Information Communication Technology (ICT) (Young, 2008). Design guidelines, such as Nielsen, is lacking with cultural elements in design principles. On the other hand, this study emphasis on the cultural elements in the design of ICT applications particularly on the user interfaces of the mobile applications.

This article begins by presenting the introduction to this research. This includes the lack of cultural design guidelines and the study of local culture. In the literature review, the aims of the study are presented together with the explanation of Malay culture in crafts. Additionally, the literature concerning local cultural mLearning applications is discussed including that pertaining to the content and aesthetic values. Next research method section presents and discusses the instruments for the design guidelines and the procedures of this research. The findings section highlights the main points from the descriptive findings of this study. The discussion section elaborates further upon the results of the findings. Finally, the article concludes by highlighting the main contribution of the findings in Human Computer Interaction as guidelines for cultural design principles and possible directions for this research.

The embedding and application of cultural design principles to the user interfaces is for the profit of local people or stakeholders. This applies to the design guidelines of mLearning apps interfaces in Malaysia. In a research conducted in a Malaysian university mLearning portal, a set of usability design guidelines has been suggested (Seong, 2006). The usability design principles: touch on user analysis, interaction, and interface design. Other principles highlighted are nationality and languages as a section of the assessment but with limited guidelines on how these could be embedded. However, the study did not suggest embedding local cultural design principles.

Another research concerning the attractiveness of utilizing local characters for Malaysia comprising Malay, Chinese and Indian from the mobile games apps was conducted to understand the appeal of local characters (Zaibon \& Shiratuddin, 2010). These apps were in accordance with the '1Malaysia' idea to increase the involvement of the diverse Malaysian cultures. Local characters were embodied via graphics and images entrenched in the mobile games apps. The apps were evaluated with primary school pupils. This resulted in students becoming fond of those games with local characters that are easy to play. However, their research neglected factors that were rooted in Malay culture, which is the foundation of the 1Malaysia solution.

Although local cultural mobile applications with appropriate local content are particularly important for students in the study of local culture, there are no appropriate guidelines for the user interface design for mobile local cultural content. This is unfortunate, as it has been reported that local cultural design elements embedded in lessons can motivate students in their learning (Abdullah \& Chandran, 
2009) for mobile applications (Diah, Ismail, Hami, \& Ahmad).

Since these culturally appropriate principles are very much close to the heart of the local Malay culture, it is very feasible to apply them to the local cultural mobile apps to learn local culture. Consequently, these design principles could be applied to assist mobile developers, as well as academics and students as a guide to use culturally appropriate design guidelines to develop more local content for learning Local Cultural Studies (LCS) studies, particularly in the Malaysian context for mobile apps.

In this research, local cultural Malay literature motivated the design principles formation. It is well noted that only two aspects are introduced in this article - heuristic evaluation, that is, local cultural embedded content, and local cultural embedded aesthetics values. The two cultural elements are the local cultural aesthetic features (e.g., local cultural motifs design from local flora and fauna; and local cultural colour inclinations), and cultural content (e.g., local art and local craft traditions). In fact, Malay culture emphasises the significance of arts and crafts (Asiapac Editorial, 2010).

Due to the significance of art and design in Malay crafts, this article showcases the well-known art and craft in design representing Malay culture, which are from traditional textiles; for example, the traditional 'Batik' and also the traditional textile of 'Songket'. Additionally, Jawi is also included to represent the local cultural craft in writing.

Batik is a very famous traditional product of the Malaysian Malay design of art and craft in textiles. The design and motif of Malay traditional textiles has been inspired from the local nature. The word Batik originates from the Malay word 'Tik' or 'Titik' which represents the dots in the process of making Batik. Different batik is worn by the Malay people for particular occasions; for example, for official functions a more contemporary type, while for daily wear the sarong, and for covering the deceased while waiting for the Islamic procession of the burial. The main distinction of Batik in Malaysia compared to Batik in Indonesia and Thailand is in the use of motifs. Meanwhile the Islamic religion's influence on the motifs and design of local Batik.

Another important Malay traditional textile is Songket. The word Songket means to hook or 'sungkit', and, in this context, refers to hooking gold and silver thread onto the cloth. Songket is widely worn by royalty and Malay people on special occasions, such as Malay weddings and the Malay celebration of the 'Aidil Fitri' festival.

Also, one of the well-known crafts includes Jawi, a type of handwriting that is popular in the Malay culture. It is one of the oldest writing scripts for the Malay language. The Jawi script is used for writing in the Malay culture and in other art and design representations. It has a strong influence on Malay culture by highlighting Malay cultural attributes. For instance, it can add more meaningful value and unique representation to the Malay language for similar applications in accordance with the Malay cultural design principles. 
These local cultural features consist of Malay and Islamic values, which as explained, are in accordance with the National Cultural Policy (Mastor, Jin, \& Cooper, 2010). The device for finding academics and students feedback and motivating conversation on this concern was a set of heuristics principles adapted from the design guidelines and mobile revisions of Nielsen (Bertini, Gabrielli, \& Kimani, 2010) with Malay cultural dimensions embedded (Ariffin \& Dyson, 2015). Hence, this study suggests the assessment of finished products, where summative evaluation feedback from the users is more appropriate for Batik, Jawi and Songket mobile applications in terms of Malay cultural content.

\section{METHODOLOGY}

This study aims to understand the concern of the lack of user interface design guidelines for culturally appropriate design guidelines for applications for mLearning. This is done by comparing the usability of the mobile local cultural apps between the preferences of students and academics for three Malay cultural mobile apps. Heuristic evaluation questionnaires were employed to compare the experience of different users when using the software (Alotaibi, 2013; Herr, Baumgartner, and Gross, 2016; Othman, Mahudin, Ahaguk, and Rahman, 2014). Three Malaysian mLearning apps were selected for the assessment. The applications focused on learning three traditional art and craft of Malaysian culture: Batik (M-Tik), Songket (M-Songket) and Jawi (Jawi Fun). These were selected for pragmatic reasons - due to the shortage of mLearning applications in Malaysia. English is widely used on this application. The users who assessed the Batik app comprised 10 academics and 51 students; 10 academics and 46 students assessed the Songket app; and 9 academics and 39 students assessed the Jawi app.

The apps were assessed on mobile phones supplied by the researcher, which consisted a diversity of devices with large screen functioning on Windows, Android and Symbian operating systems. The period of the assessment lasted from 15 to 30 minutes for each participant, with academics conducting their assessment individually, and two or three students conducting their assessments concurrently, with one phone for each one of them. Throughout the assessments the researcher performed as a spectator and helped the users if they experienced problem in testing the mobile applications.

\section{Participants}

The students and academics were recruited on a voluntary basis and based on their availability. The participants who took part in this study came from two public Malaysian universities. The academics taught subjects, such as Local Culture and National Heritage, Creative Movement, History, Cooking, Drama and Theatre, Education Action Research, Batik Textiles, Malay Drums and Ceramics. In addition, a Science academic was included to investigate the possibility of using mLearning to embed LCS in Science subjects. The students were studying Local Culture and National Heritage, History, Cooking, Malay Wood Craft, Creative Movement, Drama and Theatre, Education Action Research, Batik Textiles, Management and Malay Drums. These subjects for the study of local culture or LCS 
are not as popular or significant as the Information Technology and Engineering subjects. Since the majority of students in Malaysian public universities come from a Malay background (Shaari, 2011), it is appropriate to focus on Malay culture in the context of our study, which took place in the public university system.

\section{Questionnaires}

The academics and students answered to a set of questions on heuristic principles, ranking each in accord to a 5-point Likert scale. This assessment provided a quantitative measure of how the applications ranked up compared to the heuristic design principles. This was the sole quantitative measurement undertaken in this research. A set of questions was developed adapted from the Nielsen Design Guidelines for mobile applications (Ariffin \& Dyson, 2015). Nielsen's Design guidelines were employed because of the extensive use of principles for heuristic evaluation, and their practicality for evaluating user interface design in terms of usability issues. It was found that guidelines, such as visibility, focus on hardware and systems, and not $100 \%$ on applications; when evaluating the applications user interfaces: "Via a mobile device, the system is visible and capable of notifying users of the status quo of information concerning: battery, network, and environmental."

A summative assessment was carried out since the apps were all completed software. Heuristics principles derived from Nielsen's Design guidelines were used for statements that probed participants' views on accessibility; consistency; good ergonomic and minimalist user interface design; readability and ease of recall; efficiency and flexibility; and realistic error management.

In order to incorporate cultural principles into the heuristic evaluation, Nielsen's design guidelines were adapted. The first principle focuses on local cultural content and the second focuses on aesthetics. The first heuristic (Rainger, 2005) - "visibility of system status" - was substituted by accessibility as this was considered to be more vital in mLearning: "Before students can engage in any mLearning activity, they must be able to effectively access and interact" with the mobile application on the device. In addition, the evaluation was protracted with heuristic design principles about Malay culture: a suitable local cultural content. The heuristic "suitable local cultural content" was adapted from the second heuristic of Nielsen Design guidelines - "match between system and the real world" following the principle that "The system should speak the user's language". The heuristic "aesthetic value according to the local culture" was adapted from Nielsen's design guidelines "aesthetics, privacy and social conventions".

\section{RESULTS AND DISCUSSION}

The data collected from the questionnaire are analyzed and discussed. 


\section{Questionnaires}

For this evaluation research, the students' and academics were invited voluntarily to evaluate the mobile applications. A total of 46 students and 10 academics evaluated Songket, 51 students and 10 academics evaluated Batik, and 39 students and 9 academics evaluated the Jawi mobile application. The findings provide descriptive statistical feedback by local academics and students for mobile applications with local cultural content. The results for each statement have been averaged to provide an overall assessment from the participants' preferences. On average, the participants placed the three applications highly. This includes local cultural content and local cultural aesthetic value. The major challenges were experienced with the touch screen interaction, navigation and error management. Nevertheless, these scored is still high which is only marginally under 4.0 on a Likert measurement of 1-5. Figure 1 shows an academician performing the heuristic evaluation and demonstrates a student performing the same test for these three mobile applications.
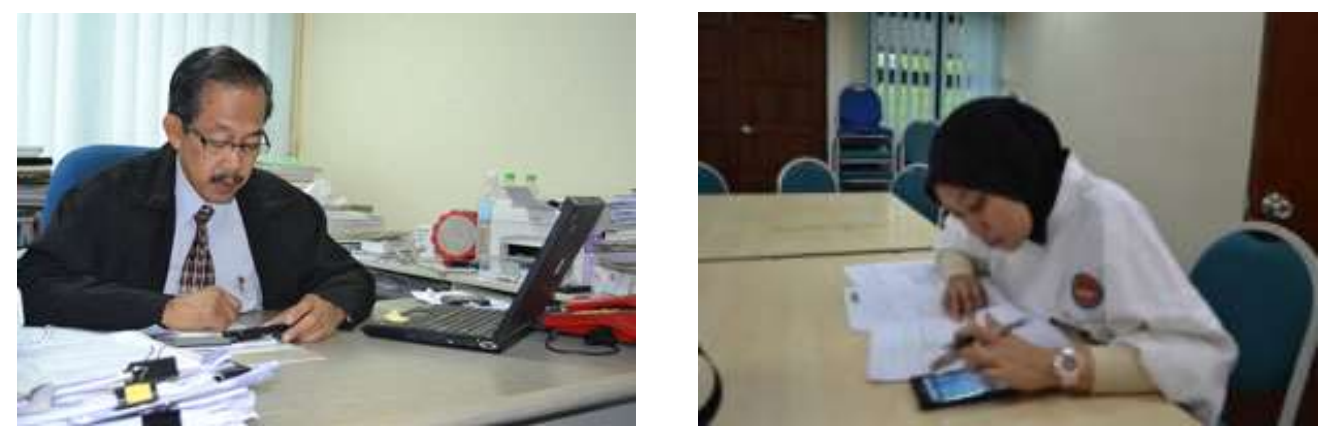

Figure 1: Participant evaluating the mobile apps: (left) the academic participant, (right) the student participant.

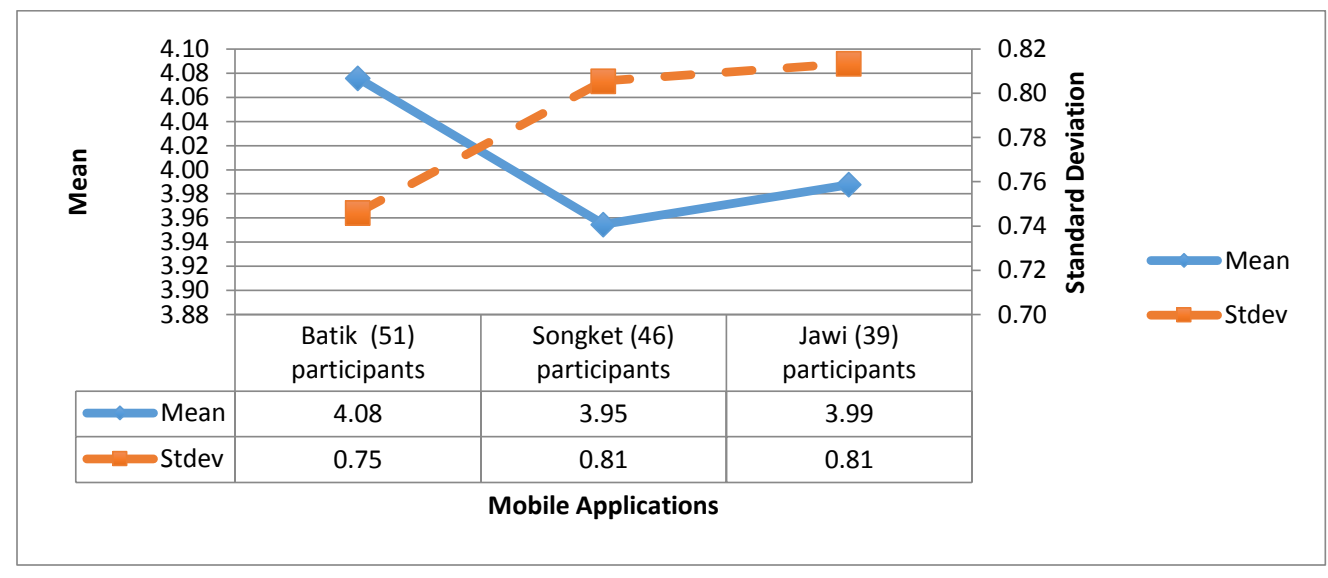

Figure 2: Graphical representation of quantitative heuristics evaluation of mobile applications for students. 
Figure 2 shows the ranking of the application means in ascending order for students' preferences with Songket having a mean of 3.95, followed by Jawi at 3.99 and Batik with the highest mean at 4.08 . The details of the further illustrations of the means for the design guidelines are depicted in Table 1. Meanwhile the aesthetics of the audio files has the lowest position of the cultural heuristics, gaining 3.90 for the Batik app and 3.87 for the Songket app.

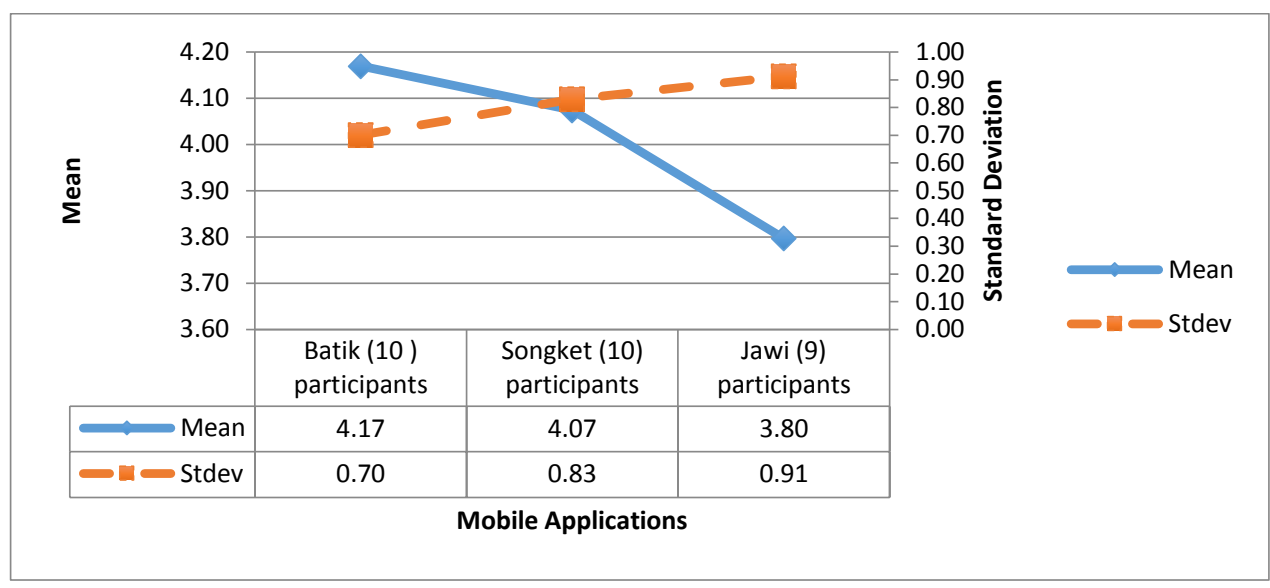

Figure 3: Graphical representation of quantitative heuristics evaluation of mobile applications for academics.

The application mean is demonstrated by Figure 3 with the position of mean in ascending order for academics' preferences from the lowest mean Jawi at 3.80, to Songket at 4.07, and the highest mean of 4.17 for Batik. Meanwhile the aesthetics of the audio files related with the apps gaining the bottom position for the cultural heuristics, gaining 3.78 for Jawi, and 4.00 for the Batik and Songket apps. Further details of the means for the design guidelines are shown in Table 1 and Table 2.

Finally, to sum up the results, the findings indicate that the Batik app emerged as the favourite app for its simplicity, functionality and aesthetically pleasing appearance. The Jawi app game, albeit more interactive and fun, lacks help instructions and the Songket application, despite being aesthetically pleasing, appears to be monotonous in terms of the usage of the colour and link issues. 
Table 1: Heuristics evaluation of mobile applications by students.

\begin{tabular}{|c|c|c|c|c|}
\hline \multirow[t]{2}{*}{ Heuristics Principle } & \multirow[t]{2}{*}{ Focus of Statement } & \multicolumn{3}{|c|}{$\begin{array}{c}\text { Mean Rankings on 5-point Likert Scales, } \\
\text { where } 5 \text { = Strongly Agree } \\
\text { Mean (Standard Deviation) }\end{array}$} \\
\hline & & $\begin{array}{c}\text { Batik } \\
(\mathrm{n}=51)\end{array}$ & $\begin{array}{l}\text { Songket } \\
(\mathrm{n}=46)\end{array}$ & $\begin{array}{c}\text { Jawi } \\
(\mathbf{n}=39)\end{array}$ \\
\hline \multirow[t]{2}{*}{ Accessibility } & $\begin{array}{l}\text { Mobile content can be accessed and interacted } \\
\text { with via a mobile phone }\end{array}$ & $4.12(0.59)$ & $4.20(0.62)$ & $4.10(0.55)$ \\
\hline & $\begin{array}{l}\text { Application can be easily found using mobile } \\
\text { phone }\end{array}$ & $4.12(0.62)$ & $4.11(0.64)$ & $4.10(0.64)$ \\
\hline \multirow[t]{3}{*}{ Consistency } & $\begin{array}{l}\text { The font layout text type, size and content are } \\
\text { very consistent }\end{array}$ & $4.29(0.58)$ & $4.04(0.70)$ & $4.10(0.72)$ \\
\hline & The images and icons are very consistent & $4.24(0.55)$ & $4.04(0.67)$ & $4.18(0.72)$ \\
\hline & The colour of the background is consistent & $4.24(0.47)$ & $4.09(0.69)$ & $4.26(0.55)$ \\
\hline \multirow{3}{*}{$\begin{array}{l}\text { Good ergonomic and } \\
\text { minimalist user interface } \\
\text { design }\end{array}$} & Simple and brief design interface & $4.16(0.54)$ & $4.09(0.66)$ & $4.05(0.65)$ \\
\hline & The touch screen interaction is good & $3.90(0.90)$ & $3.85(0.87)$ & $3.79(1.00)$ \\
\hline & The interaction via the virtual keyboard is good & $3.78(0.90)$ & $3.74(0.71)$ & $3.77(0.93)$ \\
\hline \multirow{3}{*}{$\begin{array}{l}\text { Readability and ease of } \\
\text { recall }\end{array}$} & The text content and application are readable & $4.22(0.54)$ & $4.11(0.71)$ & $4.03(0.78)$ \\
\hline & The pictorial content is readable & $4.20(0.60)$ & $4.30(0.63)$ & $4.21(0.61)$ \\
\hline & All the navigation steps are easy to remember & $3.69(0.88)$ & $3.91(0.84)$ & $3.79(0.92)$ \\
\hline \multirow[t]{4}{*}{ Efficiency \& Flexibility } & Can search text content fast & $4.10(0.73)$ & $3.74(0.95)$ & $3.67(1.01)$ \\
\hline & Can search the photos fast & $4.02(0.81)$ & $3.78(0.89)$ & $3.79(0.98)$ \\
\hline & Can navigate easily using the hyperlinks & $3.90(0.88)$ & $3.59(0.93)$ & $3.82(0.82)$ \\
\hline & Can navigate easily using available buttons & $3.90(0.81)$ & $3.61(1.02)$ & $3.69(0.95)$ \\
\hline \multirow[t]{2}{*}{ Realistic error management } & $\begin{array}{l}\text { Application will not close immediately without } \\
\text { warning }\end{array}$ & $3.75(1.02)$ & $3.61(1.04)$ & $3.59(1.21)$ \\
\hline & Application launches without error & $4.14(0.80)$ & $3.87(1.11)$ & $3.95(0.92)$ \\
\hline \multirow{2}{*}{$\begin{array}{l}\text { Suitable content for local } \\
\text { culture }\end{array}$} & Mobile content is suitable for local culture & $4.25(0.69)$ & $4.02(0.68)$ & $4.23(0.54)$ \\
\hline & Cultural content is easy to learn & $4.22(0.64)$ & $4.15(0.63)$ & $4.38(0.59)$ \\
\hline \multirow[t]{4}{*}{$\begin{array}{l}\text { Aesthetic value according } \\
\text { to local culture }\end{array}$} & $\begin{array}{l}\text { The text presentation is in accordance with local } \\
\text { culture }\end{array}$ & $4.18(0.68)$ & $4.07(0.61)$ & $3.90(0.75)$ \\
\hline & The graphics presentation respects local culture & $4.22(0.70)$ & $4.11(0.71)$ & $4.10(0.72)$ \\
\hline & The audio presentation follows local culture & $3.90(0.90)$ & $3.87(0.81)$ & $4.05(0.69)$ \\
\hline & The animation follows local culture & $4.24(0.65)$ & $4.07(0.71)$ & $4.15(0.59)$ \\
\hline \multicolumn{2}{|c|}{ Mean and Standard Deviation Across All Heuristics } & $4.08(0.75)$ & $3.95(0.81)$ & $3.99(0.81)$ \\
\hline
\end{tabular}


Table 2: Heuristics evaluation of mobile applications by academics.

\begin{tabular}{|c|c|c|c|c|}
\hline \multirow[t]{2}{*}{ Heuristics Principle } & \multirow{2}{*}{ Focus of Statement } & \multicolumn{3}{|c|}{$\begin{array}{c}\text { Mean Rankings on 5-point Likert Scales, } \\
\text { where } 5 \text { = Strongly Agree } \\
\text { Mean (Standard Deviation) }\end{array}$} \\
\hline & & $\begin{array}{c}\text { Batik } \\
(\mathbf{n}=\mathbf{1 0})\end{array}$ & $\begin{array}{l}\text { Songket } \\
(\mathbf{n}=10)\end{array}$ & $\begin{array}{c}\text { Jawi } \\
(\mathbf{n}=9)\end{array}$ \\
\hline \multirow[t]{2}{*}{ Accessibility } & $\begin{array}{l}\text { Mobile content can be accessed and interacted } \\
\text { with via a mobile phone }\end{array}$ & $4.40(0.52)$ & $4.50(0.53)$ & $4.56(0.53)$ \\
\hline & $\begin{array}{l}\text { Application can be easily found using mobile } \\
\text { phone }\end{array}$ & $4.00(0.94)$ & $4.20(0.42)$ & $4.00(0.87)$ \\
\hline \multirow[t]{3}{*}{ Consistency } & $\begin{array}{l}\text { The font layout text type, size and content are } \\
\text { very consistent }\end{array}$ & $4.40(0.70)$ & $4.40(0.70)$ & $3.89(0.93)$ \\
\hline & The images and icons are very consistent & $4.20(0.79)$ & $4.40(0.70)$ & $3.89(0.93)$ \\
\hline & The colour of the background is consistent & $4.30(0.67)$ & $4.40(0.70)$ & $3.89(0.93)$ \\
\hline \multirow{3}{*}{$\begin{array}{l}\text { Good ergonomic and } \\
\text { minimalist user interface } \\
\text { design }\end{array}$} & Simple and brief design interface & $4.30(0.67)$ & $4.40(0.70)$ & $3.89(0.78)$ \\
\hline & The touch screen interaction is good & $4.00(0.47)$ & $3.50(1.18)$ & $3.44(0.88)$ \\
\hline & The interaction via the virtual keyboard is good & $3.80(0.63)$ & $3.30(1.06)$ & $3.33(0.71)$ \\
\hline \multirow{3}{*}{$\begin{array}{l}\text { Readability and ease of } \\
\text { recall }\end{array}$} & The text content and application are readable & $4.40(0.52)$ & $4.00(0.82)$ & $3.44(1.01)$ \\
\hline & The pictorial content is readable & $4.40(0.52)$ & $4.20(0.42)$ & $3.89(1.05)$ \\
\hline & All the navigation steps are easy to remember & $4.10(0.74)$ & $3.90(0.88)$ & $3.78(0.83)$ \\
\hline \multirow[t]{4}{*}{ Efficiency \& Flexibility } & Can search text content fast & $4.10(0.74)$ & $3.80(0.92)$ & $3.44(1.01)$ \\
\hline & Can search the photos fast & $4.00(0.82)$ & $3.80(0.92)$ & $3.44(0.88)$ \\
\hline & Can navigate easily using the hyperlinks & $3.90(0.74)$ & $3.90(0.88)$ & $3.67(1.00)$ \\
\hline & Can navigate easily using available buttons & $3.90(0.99)$ & $3.70(0.82)$ & $3.78(0.97)$ \\
\hline \multirow[t]{2}{*}{ Realistic error management } & $\begin{array}{l}\text { Application will not close immediately without } \\
\text { warning }\end{array}$ & $3.90(0.74)$ & $4.00(0.94)$ & $3.78(0.97)$ \\
\hline & Application launches without error & $4.30(0.82)$ & $4.10(0.57)$ & $3.56(0.88)$ \\
\hline \multirow{2}{*}{$\begin{array}{l}\text { Suitable content for local } \\
\text { culture }\end{array}$} & Mobile content is suitable for local culture & $4.60(0.52)$ & $4.40(0.70)$ & $4.00(1.00)$ \\
\hline & Cultural content is easy to learn & $4.10(0.99)$ & $4.30(0.67)$ & $4.00(1.00)$ \\
\hline \multirow[t]{4}{*}{$\begin{array}{l}\text { Aesthetic value according } \\
\text { to local culture }\end{array}$} & $\begin{array}{l}\text { The text presentation is in accordance with local } \\
\text { culture }\end{array}$ & $4.40(0.52)$ & $4.30(0.67)$ & $4.00(1.00)$ \\
\hline & The graphics presentation respects local culture & $4.30(0.48)$ & $4.00(1.25)$ & $4.00(1.00)$ \\
\hline & The audio presentation follows local culture & $4.00(0.67)$ & $4.00(0.94)$ & $3.78(0.97)$ \\
\hline & The animation follows local culture & $4.10(0.57)$ & $4.20(0.63)$ & $3.89(0.93)$ \\
\hline \multicolumn{2}{|c|}{ Mean and Standard Deviation Across All Heuristics } & $4.17(0.70)$ & $4.07(0.83)$ & $3.80(0.91)$ \\
\hline
\end{tabular}




\section{Discussion}

This paper focuses on the descriptive quantitative enunciation from the academics and students for three mobile applications. The research has gone through several phases of evolution for the cultural design principles. The original design criteria were adapted from Nielsen's Design Guidelines in terms of the user interface principles' guidelines. It is debatable whether Nielsen's design guidelines were developed without explicitly considering the presence of culturally appropriate principles. The literature behind this study provides the vision that culture has a significant role in supporting usability.

\section{Local Content and Aesthetics Values in Design Principles Opportunities}

The culturally appropriate design guidelines projected are appropriate local cultural content and aesthetic values. There is the opportunity within non-LCS subjects to use the culturally appropriate design principles for the aims of mLearning. The use of culturally appropriate design principles for user interface designs could be applied to the content of other subjects, which are not specifically LCS subjects. In addition, this could be used to embed the design of motifs, such as small icons or images, or add Jawi script to the title of subjects that have no LCS content.

\section{Significance of Bahasa Malaysia and Local Philosophy}

Clearly, the local or native language, which is Bahasa Malaysia or Bahasa Melayu, is also considered to be significant (Mastor et. al, 2000) in these findings. Because the applications were designed using the English language it introduced difficulty for non-English native speakers. This also applies to Jawi beginners who prefer an introduction in Bahasa Malaysia. Additionally, the local philosophy is considered important, which reflects the behaviour and attitude of local people, especially when it refers to the national cultural policy (Mastor et. al, 2000), which is founded on the Malay culture and Islamic beliefs. Likewise, other cultural values could be adapted if compatible with the Malay culture.

\section{General Usability Design Challenges}

Cultural design principles and general usability guidelines show an important factor in determining the usability of local mobile applications (Ariffin \& Dyson, 2015). General usability principles were vital, for example, consistency, minimalist design, and efficiency, flexibility and error management. It is crucial to identify these design principles in the assessment of the mLearning apps, otherwise the apps will receive negative comments from participants. For instance, the absence of a 'Help' function for the Jawi game made it difficult for users to use the app smoothly. The evaluation further disclosed that mLearning apps need to consider the readability challenges, as included in the design principles, has been demonstrated to be significantly vital. 


\section{CONCLUSION}

The contribution of this article is in entrenching the ideas of local cultural design in mobile applications for the evaluation of heuristic evaluation (Ariffin \& Dyson, 2015). It adds further knowledge to the Human Computer Interaction by embedding the local cultural design principles of mobile applications to existing design guidelines.

This paper is used to evaluate the local cultural mobile apps in developing design guidelines for the cultural principles. The conclusions for this research are additional to the design principles with no importance in terms of ranking:

1. Suitable content for local culture

2. Local cultural appealing aesthetic value

3. Native Language (BM and Multilingual)

4. Philosophical Values

These results could further be extended to other cultural contexts and mobile application products for either LCS or non-LCS subjects, particularly in developing countries.

\section{ACKNOWLEDGEMENTS}

The author would like to thank the funding body for this research during his study: Ministry of Higher Education Malaysia and also the Malaysian participants. Additionally, the author would like to thank Dr. Laurel Evelyn Dyson from the University of Technology Sydney for her advice and for the loan of mobile phones while this research was being conducted.

\section{REFERENCES}

Abdullah, N., \& Chandran, S. K. 2009, Aug 27. Cultural elements in a Malaysian English language textbook. Retrieved from: http://ddms.usim.edu.my/handle/123456789/713.

Alotaibi, M. B. 2013, April. Assessing the usability of university websites in Saudi Arabia: A heuristic evaluation approach. In Information Technology: New Generations (ITNG), 2013 Tenth International Conference, 138-142. Las Vegas, USA.

Ariffin, S. A., \& Dyson, L. E. (2015). Culturally Appropriate Design of Mobile Learning Applications in the Malaysian Context. Cross-Cultural Design Applications in Mobile Interaction, Education, Health, Transport and Cultural Heritage, 3-14.

Asiapac Editorial. (2010). Gateway to Malay culture. 5th Edn. Singapore: Asiapac Books.

Bertini, E., Gabrielli, S., and Kimani, S. (2006). Appropriating and assessing heuristics for mobile computing. Proceedings of the Working Conference on Advanced Visual Interfaces, 119-126. Venice, Italy.

Diah, N.M., Ismail, M., Hami, P.M.A., \& Ahmad, S. (2011). Assisted Jawi-writing (AJaW) software for children. Open Systems (ICOS), 2011 IEEE Conference, 322-26, Langkawi, Malaysia.

Herr, S., Baumgartner, N., \& Gross, T. (2016). Evaluating Severity Rating Scales for Heuristic Evaluation. Proceedings of the 2016 CHI Conference Extended Abstracts on Human Factors in Computing Systems, 3069-3075, New York, USA. 
A Comparative Analysis for the Enhancement of Design of Local Cultural Mobile Applications

Seong, D. S. K. (2006). Usability guidelines for designing mobile learning portals. Proceedings of the 3rd international conference on Mobile technology, applications \& systems, 1-8. Bangkok, Thailand

Shaari, M.N.G. (2011). Wither the bumiputera identity of Universiti Teknologi MARA (UiTM). Kajian Malaysia (Malaysia Study), 29(2): 67-89.

Rainger, P. (2005). Accessibility and mobile learning. Mobile learning: A handbook for educators and trainers, 57-69. Oxon, UK: Routledge.

Young, P. A. 2008. Integrating culture in the design of ICTs. British Journal of Educational Technology, 39(1): 6-17.

Zaibon, S. B., and Shiratuddin, N. (2010), April. Heuristics evaluation strategy for mobile game-based learning. Wireless, Mobile and Ubiquitous Technologies in Education (WMUTE), 2010 6th IEEE International Conference, 127-31. Kaohsiung, Taiwan. 